\title{
The sovereignty of the Crown Dependencies and the British Overseas Territories in the Brexit era
}

\author{
Maria Mut Bosque \\ School of Law, Universitat Internacional de Catalunya, Spain \\ MINECO DER 2017-86I38, Ministry of Economic Affairs \& Digital Transformation, Spain \\ Institute of Commonwealth Studies, University of London, UK \\ mariamut@uic.es (corresponding author)
}

\begin{abstract}
This paper focuses on an analysis of the sovereignty of two territorial entities that have unique relations with the United Kingdom: the Crown Dependencies and the British Overseas Territories (BOTs). Each of these entities includes very different territories, with different legal statuses and varying forms of self-administration and constitutional linkages with the UK. However, they also share similarities and challenges that enable an analysis of these territories as a complete set. The incomplete sovereignty of the Crown Dependencies and BOTs has entailed that all these territories (except Gibraltar) have not been allowed to participate in the 2016 Brexit referendum or in the withdrawal negotiations with the EU. Moreover, it is reasonable to assume that Brexit is not an exceptional situation. In the future there will be more and more relevant international issues for these territories which will remain outside of their direct control, but will have a direct impact on them. Thus, if no adjustments are made to their statuses, these territories will have to keep trusting that the UK will be able to represent their interests at the same level as its own interests.
\end{abstract}

Keywords: Brexit, British Overseas Territories (BOTs), constitutional status, Crown Dependencies, sovereignty

https://doi.org/10.24043/isj.114 • Received June 2019, accepted March 2020

(C) 2020-Institute of Island Studies, University of Prince Edward Island, Canada.

\section{Introduction}

This paper analyses the sovereignty of two territorial categories that have unique relations with the United Kingdom: the Crown Dependencies (CDs) and the British Overseas Territories (BOTs). Each of these categories includes very different territories, with different legal statuses and varying forms of self-administration and constitutional linkages with the UK. However, they also share similarities and challenges that enable an analysis of these territories as a complete set. In this sense, they are both groups of self-governing territories that fall under British sovereignty and face common challenges that directly impact their internal and external capacities to decide on key issues.

This paper analyses the differences and similarities of these heterogeneous territories. Particular attention is paid to their constitutional statuses. Moreover, this paper discusses whether the current status of these territories is still appropriate and safe, given the present 
circumstances derived from Brexit. Another issue addressed in this paper is whether these territories' new forms of sovereignty are sufficient to make them real actors on the international scene. It is thus important to note that, even today, the major roles in international relations, such as the conclusion of international treaties or full membership of international organisations, require these territories to be full sovereign subjects. Finally, this paper focuses on how the UK's decision to leave the European Union (Brexit) has impacted the incomplete sovereignty of the CDs and BOTs. Despite these territorial entities having unique relationships, representations, and legal connections to the EU, none of them, except Gibraltar, had the option to participate in the 2016 Brexit referendum or in the withdrawal negotiations with the EU. However, it is reasonable to assume that Brexit is not an exceptional situation. In the future there will be more and more relevant international issues for these territories which will remain outside of their direct control, but will have a direct impact on them. Thus, if no adjustments are made to their statuses, these territories will have to keep trusting that the UK is able to represent their interests at the same level as its own interests.

As a final clarification, regarding the BOTs, it is important to highlight that a more detailed analysis has been undertaken for Gibraltar. This is mainly due to the fact that this paper pays special attention to the Brexit impact on the sovereignty of these entities, and Gibraltar is the only BOT which is part of the European Union. Hence, it is the territory in which a greater impact can be expected.

\section{Comparative analysis of the Crown Dependencies' and British Overseas Territories' constitutional statuses}

The Crown Dependencies and the British Overseas Territories (BOTs) are two different types of territorial entities that are the results of unique historic and constitutional realities. As a result of their different histories and relationships with the UK, each of these entities has its own constitutional status. The territories classified as Crown Dependencies are the Isle of Man and the Channel Islands. The BOT list includes the following fourteen territories: Anguilla; Bermuda; British Antarctic Territory; British Indian Ocean Territory; British Virgin Islands; Cayman Islands; Falkland Islands; Gibraltar; Montserrat; Pitcairn Island, Henderson, Ducie and Oeno Islands; St Helena, Ascension and Tristan da Cunha; Sovereign Base Areas; South Georgia and South Sandwich Islands; and Turks and Caicos Islands. All but one of the Crown Dependencies and BOTs is an island territory; the one exception, Gibraltar, is a peninsular exclave that has in the past been analysed in terms of its island-like characteristics (e.g., Gold, 2016; Skinner, 2002).

From a geographic perspective, the Crown Dependencies are neither large in size nor population. The Isle of Man has a population of 85,249 and the total land area is $570 \mathrm{~km}^{2}$ (Worldometers, 2019b). The Channel Islands have a total population of 166,661 and the total land area is $190 \mathrm{~km}^{2}$ (Worldometers, 2019a). The Isle of Man is situated in the Irish Sea, between Great Britain and Ireland. The Channel Islands fall into two separate self-governing bailiwicks: the Bailiwick of Jersey (including the uninhabited islands of the Minquiers, Ecrehous, Les Dirouilles, and Les Pierres de Lecq) and the Bailiwick of Guernsey (consisting of Guernsey, Alderney, Sark, Herm, Jethou, Brechou, and Lihou). The Channel Islands are located just off the Normandy coast of France, mainly in the Bay of St Malo, within the English Channel. The BOTs are very different in terms of geography and environmental 
conditions. While Gibraltar is located on the European continent, Tristan da Cunha is the most remote inhabited island in the world, about 2,800 km west of Cape Town. Population sizes range from zero in uninhabited territories, like the British Antarctic Territory, to 60,833 in Bermuda, which holds the highest population of all the British Overseas Territories (World Population Review, 2019). In terms of economic performance, Bermuda has an economy roughly the size of all the other BOTs combined, whereas territories such as Pitcairn and Anguilla are relatively poor (House of Commons Foreign Affairs, 2019).

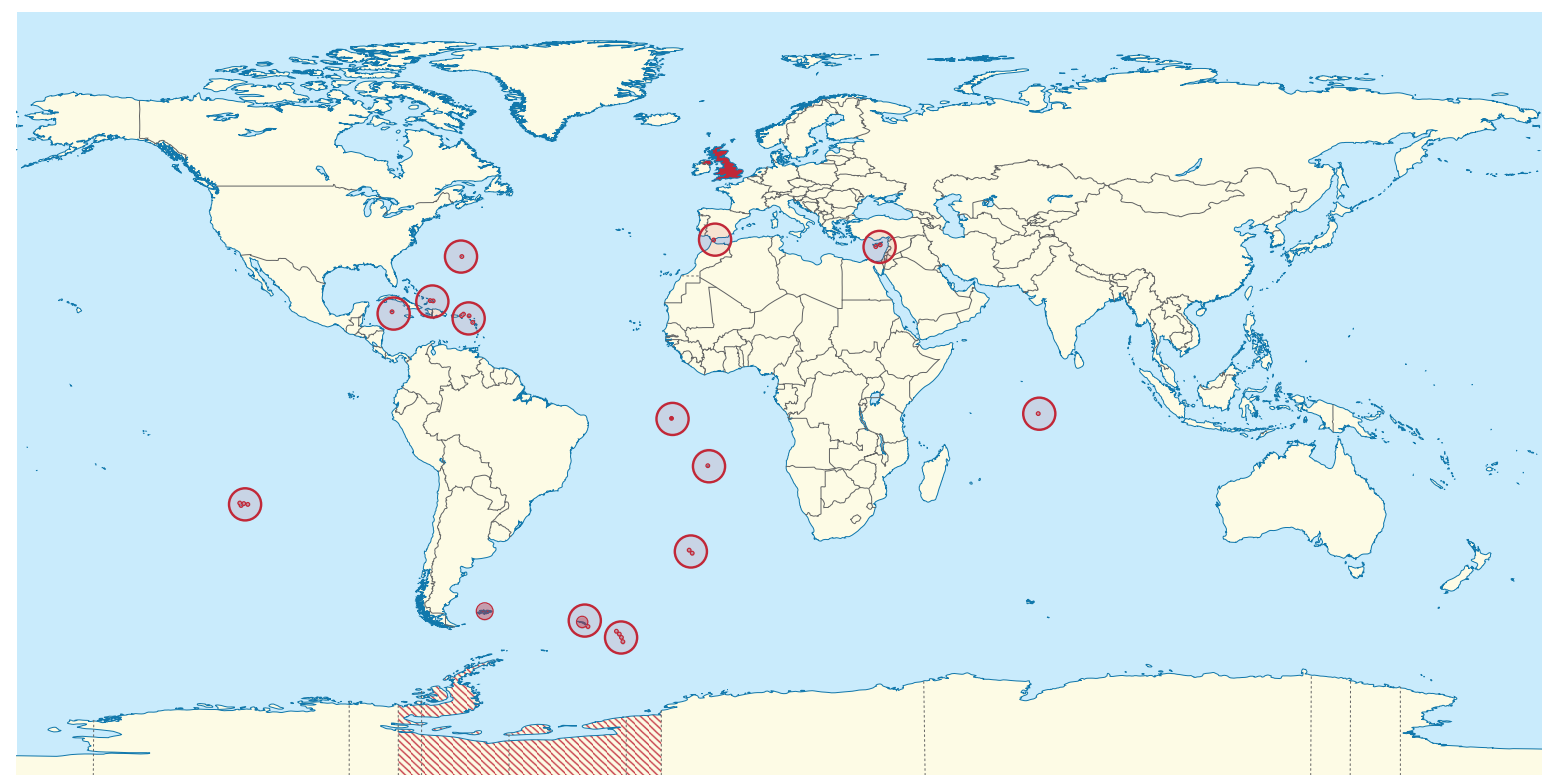

Figure 1. Map of the United Kingdom and British Overseas Territories. Source: CRob984, https://commons.wikimedia.org/wiki/File:United Kingdom (\%2Boverseas territories) in the World (\%2BAntarctica claims).svg

Historically, the Crown Dependencies differ from one another. The Channel Islands are considered to be the remnants of the Duchy of Normandy, while the Isle of Man was in the past connected to Scandinavian rulers. The Crown Dependencies, unlike the BOTs, have never been colonies of the UK (House of Commons Foreign Affairs, 2019). As for the BOTs, in many ways they are considered to be the last remnants of Britain's imperial past. The history of these territories also differs from each other. In the case of Gibraltar, this territory was captured during the Spanish War of Succession in 1704 and, according to the Treaty of Utrecht, Spain yielded in perpetuity to the Crown of Great Britain "the full and entire propriety of the town and castle of Gibraltar, together with the port, fortifications, and forts thereunto belonging" (Gibraltar Government, 2019).

In terms of sovereignty, neither the Crown Dependencies nor the BOTs are sovereign territories. They are both self-governing territories which fall under British sovereignty. However, it is important to highlight that they have a different constitutional link with the UK. The Crown Dependencies have never been colonies, because they were feudatory kingdoms subject to the kings of England; but in the roles of the Lord of Mann in the case of the Isle of Man and the Duchy of Normandy in the case of the Channel Islands, they are selfgoverning possessions of the British Crown. "The Crown Dependencies are autonomous and 
self-governing, with their own, independent legal, administrative and fiscal systems" (House of Commons Justice Committee, 2010). They have their own directly elected legislative assemblies and their own courts of law. Therefore, although these territories have a great degree of self-government, they are not sovereign states. They are Crown Dependencies with an ad hoc status, which is the result of their unique historic relationship with the British Crown. Regarding the BOTs, their status is the result of an evolutionary historical process. Before the 1981 British Nationality Act, BOTs were considered colonies under British law. After 1981, they were renamed 'British dependent territories' and, since 2002, they are 'British Overseas Territories' (House of Commons Justice Committee, 2010).

Neither the Crown Dependencies nor the BOTs are part of the United Kingdom, so they cannot elect representatives to Westminster. However, in recent times, there have been advocates like Conservative MP Andrew Rosindell (qtd. in Jersey Evening Post, 2017) who claim that they should have their own political representatives in London. He argues that "Scotland, Wales and Northern Ireland all have semi-independent governments, but are still represented by MPs in Westminster, who have the right to vote in Parliament, and it is 'unfair' that other British jurisdictions do not." In the same vein, $40 \%$ of the electorate of Gibraltar, including Gibraltar's Chief Minster Fabian Picardo, have already signed a petition to have a representative in Westminster (Ginnangeli, 2018). Picardo (qtd. in Gibraltar Insight, 2018) says that "With Brexit on the horizon, it is even more important that Gibraltar should have a representative at the House of Commons in Westminster."

Both the Crown Dependencies and BOTs have their own institutional structures. Queen Elizabeth II is the Head of the Crown Dependencies, but, as previously mentioned, in Her role of the Lord of Mann and the Duchy of Normandy. In both the Channel Islands and the Isle of Man, the Queen is personally represented by the Lieutenant Governor. In the Channel Islands, there is a Lieutenant Governor in each bailiwick. However, it is important to highlight that the different territories that make up the Crown Dependencies have their own institutions, statutory peculiarities, and territorial divisions, which are different from each other.

In this sense, in the Channel Islands, each bailiwick is headed by a bailiff who is the President of the States and of the Royal Court. He or she holds legislative power and exercises judicial power. The States-a term which derives from the French term Etats-is the Legislative Assembly of the Channel Islands. The Isle of Man's legislative assembly is known as the Tynwald: it is considered to be the world's oldest continuously working parliament in existence and the only working example of a tricameral legislature, dating back to its Viking origins over 1,000 years ago (The Parliament of the Isle of Man, 2019). Moreover, there are institutional differences between the Bailiwick of Jersey and the Bailiwick of Guernsey: for example, the legislative structure of the Bailiwick of Guernsey is more complex than that of Jersey because it includes the Parliament of Sark (called the Chief Pleas) and the Parliament of Alderney (known as the States of Alderney). Regarding the BOTs, every territory has its own institutions, but, in general terms, BOTs have a similar institutional structure (The Parliament of the Isle of Man, 2019).

Those territories that have a high level of self-government have their own governments, heads of government, and political party systems. In the case of Gibraltar, the head of the government is the Chief Minister; in the case of Bermuda and the Cayman Islands, it is the Premier. These territories have their own legislative assemblies, which are directly elected by 
their citizens. They also have their own judicial courts based on common law, but a final appeal may be heard by the Judicial Committee of the Privy Council sitting in London.

With regard to the constitutional relationship of the Crown Dependencies with the UK, this is maintained through the Crown and is not enshrined in a formal constitutional document. The UK Government is responsible for the defence and international relations of the Islands. The Crown, acting through the Privy Council, is ultimately responsible for ensuring their good government (Ministry of Justice, 2019). By contrast, the Overseas Territories are considered by the UN Committee of 24 as non-self-governing territories, despite all BOTs declaring satisfaction with their current status and not having requested a change in their status. In this sense, Gibraltar has repeatedly asked to be removed from the list and considers its "presence on the UN list of Non-Self-Governing Territories is an anachronism" (House of Commons Foreign Affairs Committee, 2008). The sovereignty of Gibraltar is a controversial issue in Anglo-Spanish relations because Spain asserts a claim over the territory.

Today, the UK government has responsibility for the international relations, defence, and good governance of the Overseas Territories and, in some territories such as Bermuda, the UK government is also responsible for internal security. The Overseas Territories have their own constitutions and domestic laws. Each BOT is constitutionally unique. The degree of self-government depends on the BOT's constitutional relationship with the UK. Larger, more developed BOTs are largely autonomous with regard to their internal affairs, as is the case with Bermuda, Gibraltar, the Falkland Islands, and others. The common thread among them is recognition of UK sovereignty, acknowledgment of the Queen as the Head of State, and British citizenship.

Moreover, there are common aspects between the Crown Dependencies and the BOTs. One of the main similarities is that the Crown Dependencies and most of the BOTs enjoy a great level of self-government, and the UK government is only responsible for their international relations, defence, and good governance. All issues related to their internal affairs fall under the competence of each of these territories. Of the powers for which the UK is responsible, the most controversial one is the good governance power. In practice, this means that if the UK considers that if good governance is not assured by the local government, it could impose direct rule. This became significant in 2009, when the UK imposed direct rule on the Turks and Caicos Islands, following a full-scale inquiry (Auld, 2013) into alleged corruption. The UK Government introduced the Turks and Caicos Islands Constitution (Interim Amendment) Order 2009 (UK Government, 2009), which suspended parts of the Overseas Territory's constitution and established interim, direct rule from Westminster, through the Governor, until the government of the territory had addressed the corruption issues (Yusuf \& Chowdhury, 2019). Direct rule has never been imposed in the Crown Dependencies. However, then-leader of the Labour Party, Jeremy Corbyn, suggested in 2016 that the "UK government should consider imposing 'direct rule' on the 14 British Overseas Territories and three Crown dependencies if they do not comply with UK tax law" (BBC News, 2016).

\section{Implications of Brexit concerning the European Union statuses of the Crown Dependencies and British Overseas Territories}

The Crown Dependencies have a special relationship with the European Union as set out in Protocol 3 of the 1972 United Kingdom's Treaty of Accession (Protocol no 3, 1972). Under 
this special relationship, the islands are neither member states nor associate members of the European Union. However, under Protocol 3, they are part of the customs territory of the Union and therefore Union customs matters - the common customs tariff, levies, and the prohibition against quantitative restrictions-apply. There is free movement of agricultural goods and derived products between the islands and the EU, and measures relating to trade in such goods with third countries are also included (Boswell, 2018).

Notwithstanding the Protocol 3 framework, there are some differences between the Crown Dependencies in terms of their relationship both with the UK and the EU, notably regarding the rights of EU citizens (including British citizens) to work. Another principal difference is that the Isle of Man has a customs and excise agreement with the UK (signed in 1979), which provides for the sharing of VAT and other revenues between the Island and the UK. Thus the Isle of Man is part of the EU customs territory and fiscal territory. Guernsey and Jersey do not apply VAT. They apply their own customs regimes set up in 1973 and the EU Common External Tariff by virtue of being part of the customs union for goods through Protocol 3. They are also part of the Common Commercial Policy for goods. While the Isle of Man is part of the UK's membership of the World Trade Organization (WTO), Guernsey and Jersey are not. [...]

While all of the Crown Dependencies cooperate where appropriate, given their geographical proximity, the relationship between the Channel Islands is in practice closer. For instance, they have a joint Channel Islands office in Brussels, whereas the Isle of Man operates a separate office. While we were told that the Crown Dependencies' interests were in alignment most of the time, this is not always so. The Chief Ministers of Jersey and Guernsey cited fishing rights as an area of disagreement between them. (House of Lords, 2017c)

Gibraltar is one of the 14 BOTs, but its territorial and political particularities (a British Overseas Territory located in Europe) make it impossible to fit it into the legal category in which the rest of the BOTs were included. Although all BOT nationals are, in principle, European citizens, these territories do not form part of the EU territory. This means they are not directly subject to EU law, but they benefit from 'associate' status given to them by the Lisbon Treaty (European Commission, 2019a). In accordance with Part Four of the Treaty on the Functioning of the European Union, overseas countries and territories are associated with the European Union. The purpose of this association is "to promote the economic and social development of the countries and territories and to establish close economic relations between them and the Union as a whole" (European Commission, 2019b).

By contrast, Gibraltar joined the European Community with the UK in 1973 and was granted a special status under Article 227(4) of the Treaty of Rome. It joined as a European territory for whose external affairs a member state is responsible, with some special arrangements. At the request of the British Government, Gibraltar was excluded from the Community Customs Area, the Common Agricultural Policy and the VAT regime (Miller, 1995). Gibraltar's special status within the European Community was directly negotiated by the UK Government, at the time of British accession. Thus, Gibraltar and the UK are parts of a single member state for the purposes of EU law (Marre, 2018). Therefore, these territories 
have three different EU statuses: the BOTs are associated territories, Gibraltar is part of the EU, and the Crown Dependencies are neither associate territories nor part of the EU, but have some links with the EU.

Since the UK is responsible for the international relations of both territorial entities, all these different territories' EU statuses were bilaterally agreed by the UK and the European Community during the British accession negotiations in the seventies. This means that neither of these entities directly negotiated their statuses with the EC. This has also been the case during the withdrawal negotiations concerning the UK's exit from the EU. The UK has negotiated on behalf of these territories. However, there are differences between the accession and withdrawal negotiations. The first difference concerns the evolution of their internal statuses during more than four decades of UK membership in the EU.

In this regard, Gibraltar deserves particular attention. This overseas territory has seen how its self-government has increased during the last few decades and, today, it has one of the highest levels of internal self-government (Miller, 2017). The second difference is the evolution of the European integration process. The third difference is the development of the EU-UK relationship and the different stages that this relationship has gone through. Finally, a big difference concerns these territorial entities' reactions towards the unilateral British decision to leave the EU. While neither the Crown Dependencies nor the BOTs officially expressed displeasure with their European statuses accorded by the UK and the EC in 1973, both territorial entities have officially expressed discontent about the UK decision to leave the EU and the fact that they cannot keep their EU statuses once the UK leaves. In this sense, the Isle of Man's former Chief Minister, Alan Bell, expressed his disappointment with the result of the referendum and his concern for the future of the UK and, more importantly, of the island. In his opinion, the Isle of Man now faces a period of uncertainty because nobody knows what the long-term effects of the 'leave' vote will be (DQ Law Firm, 2016). Clegg (2016, p.5) shares the same concerns as Bell regarding the BOTs' future:

The consequences of the decision by the UK electorate to 'Leave' the EU are still uncertain. No one involved in the forthcoming negotiations has much idea over how long they might take, or how any future relationship between the UK and the EU might be organised. Thus for the BOTs, there are concerns over whether they could lose an important source of political, economic and financial support.

The articulation of a future relationship between the BOTs and the EU is not going to be easy, because the interests of the territories are not at all uniform when it comes to the EU.

If we focus on the different EU statuses of these entities, we can appreciate their different involvement in the UK's decision to leave. Therefore, because the Crown Dependencies are not part of the EU, their citizens were not allowed to participate in the withdrawal referendum. The same happened with BOTs citizens, although these territories have an associated status; because they are not part of the EU, they were not allowed to vote. It is important to mention that despite the Crown Dependencies and BOTs not being EU members, their special relationship with the EU will end when the UK's membership comes to an end. Thus, the decision to leave, which was taken without their formal participation in the referendum, will have direct implications for their future. From a legal and political perspective, nothing prevented the UK from including all these territorial entities in the 
referendum process, but the UK decided not to let them vote. In fact, the citizens of some of the BOTs have expressed regret that they had no chance to vote and are concerned about their future (Hare, 2017). In a similar sense, the Caribbean council issued a statement on 13 March 2016, where the BOTs expressed their discontent about the likely 'leave' result and the effect on the special status that the UK's Overseas Territories in the Caribbean have with Europe (Caribbean Council, 2019).

In this sense, Clegg (2018) explains that BOTs are strongly in favour of the UK remaining part of the EU and are pushing the UK Conservative government to remain as close to the EU as possible, because the EU has been a key interlocutor and has provided direct support to strengthen the bonds between them. This author points out that the advantages derived from the EU relationship are various, and in many cases significant, focused particularly around security trade, aid, free movement of citizens, and political dialogue. Note, however, that any accruing benefits flowing from the UK's current EU membership vary between the territories. The territories have free access to the EU market, and this is particularly important for several of them. For the Falkland Islands, there is grave doubt that other markets offer the same opportunities as the present EU market. For Gibraltar, losing access to the Single Market in services would be a "severe blow" (House of Lords European Union Committee, 2017a, p. 11). Beyond trade, a particular worry is in relation to the provision of aid. All the territories, to some extent, receive EU financial support. In this sense, Leslie Jaques, Pitcairn's representative in Europe, argued that "to lose all of that [aid] for us would be quite catastrophic" (House of Lords European Union Committee, 2017b, p.6).

Moreover, Clegg (2018) adds that apart from trade advantages and aid disbursements, the EU has played a vital role in the collective recognition of UK sovereignty over the Falkland Islands and Gibraltar and has provided a political platform for these territories to exert their influence in Brussels. The fears of not including the interests of these territories in a final Brexit deal, or the eventual application of direct rule due to their tax systems, has led them to mistrust in their relations with the UK. In fact, as stated by an official from the British Virgin Islands, "in many cases, some territories benefit more from the EU relationship than the relationship with Britain" (Wheatley, 2018, p. 3).

The BOTs' fears of being eventually disadvantaged by Brexit seem well founded since, according to Bishop and Clegg (2018), almost two years after the Brexit vote, the UK has still little to offer their territories, and significant uncertainty remains. Apart from the commitment by the UK to cover the funding of projects to 2020, little else is known, and it is clear that as the negotiations between the UK and the EU enter their final stages, the interests of Overseas Territories will be a marginal concern. Already the UK is saying that the territories should not be a liability for them during the negotiations, particularly in relation to their financial services industries. Therefore, the territories are exploring new options to advance their interests that, at the very least, are pushing against the limits of their ties with the UK. This is particularly true of several of the territories in the Caribbean. These territories realise they must be more proactive in mitigating potential new vulnerabilities. So those in the Caribbean, for example, are exploring how their links with groups such as CARICOM, the Organisation of Eastern Caribbean States (OECS), and CARIFORUM can be enhanced, which in turn could strengthen their own ties to the EU. The observer status of the ACP group is also being examined (Bishop \& Clegg, 2018). 
In keeping with this same line, Benwell and Pinkerton (2016) explain that the formal recognition of supranational organisations like the EU is fundamental for BOTs more broadly, and particularly those that are subject to competing sovereignty claims. These territories fear that UK withdrawal from the EU could lead to short-term attempts to question the viability and legitimacy of their statuses by their unfriendly and considerably larger neighbours, such as the way in which leaving the EU means the loss of a key protection against Spain's claims over Gibraltar.

In the case of Gibraltar, as part of the EU, Gibraltarians were allowed to participate in the Brexit referendum. Gibraltar's chief minister, Fabian Picardo, repeatedly expressed his opposition to leaving the EU and actively campaigned to remain (The Local, 2016). Apart from the economic and social implications that Brexit may have for Gibraltar, the great fear of Gibraltarians focuses on the loss of its constitutional status and its political security. "It is therefore not Brexit per se that Gibraltarians fear most, but rather what Spain is able to do once Gibraltar loses the legal protections afforded by its EU status" (Trinidad, 2017, p.2). Leaving the EU will give Spain much wider freedom when it comes to deciding issues related to Gibraltar. The EU will not be able to act as an intermediary between the parties anymore, as it did in 2013 during the border controls crisis. The UK will be considered to be a third state and will not be heard on the same terms as a member state. Gibraltar will lose another international forum where the UK can influence and advocate regarding Gibraltar's status. Gibraltar will be more vulnerable. In fact, these fears have started to materialise: Spain has pressured the EU Institutions to describe Gibraltar as a 'colony' in a footnote of a European Union regulation draft on reciprocal visa-free access for EU and UK nationals after Brexit (Council of the European Union, 2019).

Gibraltar has always been a strong supporter of the European integration project-much more so than the UK. Gibraltarians have actively fought for more involvement in the EU. Although the UK negotiated the European status of Gibraltar with no official representation in the EU institutions, in 1999 Gibraltarians achieved the recognition of their right to vote in the European Parliament elections before the European Court of Human Rights (1999). Nevertheless, the most important demonstration of their loyalty to the EU has been their almost unanimous support in the 2016 referendum, in which almost $96 \%$ of Gibraltarians voted in favour of remaining in the EU. However, it was to no avail. Gibraltar will have to leave the EU on the same terms as the UK, because the EU has not granted an agreement to enable Gibraltar to continue enjoying its current special relationship.

\section{Lack of sovereignty of the Crown Dependencies and British Overseas Territories within the framework of the Brexit process}

The traditional concept of sovereignty or the concept of Westphalian sovereignty has its origins in the negotiations that resulted in the $17^{\text {th }}$-century Peace of Westphalia in Europe. Arguably, the Peace of Westphalia was the foundation for early $19^{\text {th }}$-century nationalism and mid- $20^{\text {th }}$-century decolonisation, leading to today's notion of state sovereignty. Today, the scope of sovereignty is undergoing constant change. For instance, according to Prinsen and Blaise (2017), non-self-governing islands are actively creating a new form of sovereignty, an 'Islandian' sovereignty. Thus, from this perspective, states not only have sovereignty, but 
other territorial entities are also able to create new forms of sovereignty which combine traditional and new ways of understanding sovereignty.

Prinsen and Blaise (2017) argue that none of today's 40-odd non-self-governing islands seems to strive for political independence from their colonial metropoles in a classic, Westphalian definition. The diverse debates on Westphalian sovereignty over the past two decades suggest that it may be undergoing fundamental modifications. Non-self-governing islands are actively and creatively modifying the moulds of Westphalian sovereignty, and contours of an 'islandian' sovereignty may be emerging. According to these authors, these islands can sign international treaties or agreements beneficial to them, but uncomfortable for their metropole and/or contrary to its interests. Nevertheless, as we will see later, regarding the BOTs and Crown Dependencies, Brexit appears to undermine this last statement.

Baldacchino (2017) points out that, much like the binary numeral system, sovereignty is often treated as indivisible. It is either 0 or 1: you either are sovereign, or you are not, with hardly any room for dithering in between. But this assumption is false: it is part of the inherent 'governmentality' of states to challenge and test this 'yes/no' principle, seeking to exploit the many, lucrative policy possibilities and niches that it creates. In keeping with this same line, Grydehøj (2016) argues that, in the past few decades, international political geographers had an oversimplified binary understanding of independence and dependence, which does not fit with territorial entities which are located on a wider spectrum of sovereignty and have an ad hoc status. This is the case for the Crown Dependencies and some of the BOTs, particularly Gibraltar.

The concept of 'islandian' sovereignty can be linked to the paradiplomacy theory explained by Bartmann (2006) regarding subnational island jurisdictions. This author notes that the quest for sovereignty as the only acceptable path to self-determination does not seem to be the burning issue in the remaining dependent territories. Many are content to maintain the security of metropolitan relationships into the distant future. Moreover, having dependent relationships allows them considerable autonomy and latitude, even in relations with the world beyond their metropolitan centre. Indeed, the capacity to engage the outside world through varying patterns of communication and representation, a phenomenon now widely termed 'paradiplomacy', is one of the developments inviting a reassessment of these small islands' once-conventional constitutional future toward sovereignty. The circumstances of these subnational island jurisdictions and the current options open to them are themselves striking evidence of a rapidly changing international system.

In Bartmann's (2006) opinion, long-standing distinctions, both legal and diplomatic, between established sovereign states and other international actors seem to be increasingly blurred by changing practices in international relations and particularly by the activities of non-sovereign and unrecognised jurisdictions in external representation. It is undeniable that these new actors have progressed in order to be recognised as international players and acquired greater external relevance. In this sense, both the Crown Dependencies and Gibraltar, which have different historical backgrounds and constitutional linkages with the UK, are self-governing territories with high levels of autonomous power. They have their own institutions, legislative capacities, and are responsible for their internal affairs. In fact, only a few areas of their sovereignty, mainly international affairs and defence, are entrusted to the United Kingdom. Both territorial entities are satisfied with their current status, and there is no official claim to become independent states. It is true that, in the case of the Crown 
Dependencies, no referendum has been held to consult about their satisfaction with their statuses, but it is also true that a referendum has not been officially requested. In Gibraltar, there have been two referenda. The first sovereignty referendum was held in Gibraltar on 10 September 1967, in which Gibraltarian voters were asked whether they wished to either 1) pass under Spanish sovereignty, with Gibraltarians keeping their British citizenship and a special status for Gibraltar within Spain, or 2) remain under British sovereignty, with institutions of self-government (Garcia, 1994). There was never any doubt as to the result. With a turnout of $95.8 \%, 12,237$ people cast their votes: 12,138 voted for Britain and only 44 for Spain, with 55 spoiled ballot papers (Garcia, 1994). Although labelled 'unofficial' in practice, the second sovereignty referendum was organised by the Government of Gibraltar and held on 7 November 2002. It only provided the option of joint sovereignty. The question was as follows: Do you approve of the principle that Britain and Spain should share sovereignty over Gibraltar? "History records that with a turnout of $88 \%$ over $99 \%$ of the electorate did not support the joint sovereignty option" (Mut-Bosque, 2018, p. 4). Moreover, the 2006 Constitution of Gibraltar recognises the right of self-determination and, based on this right, the UK will "never enter into arrangements under which the people of Gibraltar would pass under the sovereignty of another state against their freely and democratically expressed wishes" (Gibraltar Government, 2006).

By contrast, the Crown Dependencies do not have written constitutions regarding their right to self-determination; there is no official written document that enshrines this right. According to Sutton, if the Crown Dependencies "were to seek independence and if, by a proper democratic means, they were to exercise that right of self-determination, I have heard it said by the United Kingdom officials that the United Kingdom would not stand in their way" (House of Commons Justice Committee, 2010).

The fact that the Crown Dependencies and Gibraltar as a BOT are satisfied with their current statuses and have not sought independence is not unusual. This could be explained by the fact that "non-self-governing islands tend to have much better development indicators than sovereign islands. Perhaps unsurprisingly, since 1983 no non-self-governing island has acquired political independence" (Prinsen \& Blaise, 2017, p.56). Regarding Gibraltar, another argument can explain the preference for keeping its current status. This is that Gibraltarians feel more politically secure by retaining their British link, because it protects them against the Spanish aspiration to recover Gibraltar. However, being dependent territories and lacking international subjectivity not only prevents these territories from directly negotiating and concluding international agreements, but also entails greater vulnerability, as the UK could unilaterally decide to detach from these territories at any time. The UK is under great pressure from the international community to complete the decolonisation process.

Only sovereign entities like states can enjoy full international capacities, such as ius contrahendi or the capacity to conclude international treaties; ius legationis or the capacity to send and receive ambassadors, consuls, envoys, and other state international representatives. Moreover, states have the capacity to sue or be sued for the breach of an international obligation, and only states can be full members of international organisations. Non-state entities can be observers or associated members of international organisations, but not full members. So, the decision to join or leave an international organisation is a unilateral and voluntary act of the state. No one can deny that the state remains at the centre of public 
international law and that no other entity has the power and prerogatives of the state in the international arena. As Barrow $(2005$, p. 2) notes, over the past few decades:

There was a never ending litany of books and articles on the crisis of the nation-state, the eclipse of the state, the retreat of the state, and even the end of the nation-state. The central theme in these eulogies was that nation-states had lost control of their national economies, currencies, territorial boundaries, and even their cultures and languages and that macroscopic forms of power were shifting from the nation-state to the global market, transnational corporations, and globalized channels of communication.

However, according to this author, these predictions have not materialised, and nation-states are the principal agents of globalisation. This author explains that this does not mean that the nation-state is undergoing a transformation process, which entails its simultaneous internationalisation, denationalisation, and destatisation, but this process should not be equated with a decline, retreat, or end of the state (Barrow \& Keck, 2017).

The Crown Dependencies and BOTs are not sovereign states, but have developed a new form of sovereignty: the 'Islandian' sovereignty (Prinsen \& Blaise, 2017). As a result of this achievement, these territories enjoy a high level of self-government. But, despite the high level of self-government that both the Crown Dependencies and the BOTs possess, the fact that these territories are not completely sovereign has resulted in the acceptance of the UK decision to leave the EU, in which they have not directly participated and with which they disagree. However, this decision will have a highly significant impact on their futures. Their lack of complete sovereignty has not allowed them to conclude any international agreement directly with the EU, in order to preserve their ad hoc status. All these territories have conferred their international relations powers to the UK in order to be represented in the best way possible. It is not always possible for the UK to represent UK interests and at the same time honour these territories' views, particularly if these views are in opposition. In this same sense, Alegre expressed doubts as to whether, in an international negotiation as wide-ranging as Brexit, the Crown Dependencies have been able to make their voices heard (House of Lords, 2017c). She also noted that the way the process has been managed "will set a precedent for future decisions on the international stage that could have even more serious consequences for the Crown Dependencies and their people" (House of Lords, 2017c).

All these territorial entities have been indirectly involved in the withdrawal negotiations. The question, however, is simply: Is such indirect involvement enough, or should they have been involved in a more direct way? Regarding the Crown Dependencies, the UK Government considers that it "has engaged the Crown Dependencies well regarding Brexit so far" (UK Parliament, 2017). However, it recognises that this engagement may be more difficult to maintain if the Crown Dependencies' interests differ from the UK's own interests in Brexit negotiations and thereafter. Thus, the House of Commons recommends "that the Government clarify its position on representing any of the Crown Dependencies' interests that differ from the UK's own in Brexit negotiations and thereafter" (UK Parliament, 2017). As for the BOTs, UK ministers have held different meetings with BOTs ministers in order to discuss the implications of Brexit for the Overseas Territories (European Sources Online, 2019). They have also requested that the UK Government furnish a more thorough reply to their specific concerns (European Sources Online, 2019). Gibraltar is being dealt with 
separately from other UK Overseas Territories because of its membership in the EU. Thus, it has had more direct participation. Gibraltar has held a series of formal meetings of the joint ministerial committee on Brexit, but it has not been able to directly negotiate a special deal with the EU with an official representation. According to Sutton (2019, p.4), the Joint Ministerial Committee provides a framework for consultations for the territories, as well as the devolved administrations (Scotland, Wales, and Northern Ireland), yet "little progress appears to have been made so far on the territories" future relations with the EU."

Therefore, despite the new forms of sovereignty developed by the Crown Dependencies and BOTs, there is an important restriction in their self-determination. The UK government is responsible for the international relations of both kinds of territorial entity. That means they have limited action in this area. While this may have been reasonable centuries ago, today, in a globalised world, it is more difficult to understand. One must not forget that most of these territories are vulnerable and have special needs (Armstrong \& Read, 2000). Thus, for these territories, it is essential to participate in the international scene and take part in an organisation like the European Union or relevant fora where their voices can be heard on a worldwide basis.

It is true that the UK has mechanisms which can provide these territories with more active participation: for instance, through a letter of entrustment, which allows these territories to conclude international treaties with states or international organisations. "The entrustment is the equivalent of full powers where the territory is going to act" (Hendry \& Dickson, 2018, p. 284). However, this is conditional upon the letter of entrustment both being issued by the UK and being requested by the third state or the international organisation. It is not a common practice, but there are precedents. For instance, on 17 April 2014, the Government of the United States of America negotiated and concluded with the Government of Gibraltar, which was entrusted by the UK, an agreement on information exchange to facilitate implementation of the Foreign Account Tax Compliance Act (US Department of the Treasury, 2014). Therefore, entrustment is a legal instrument which depends on the political will of the UK and the other state or international organisation involved. Regarding the Brexit negotiations, Gibraltar could have concluded its own agreement in order to keep its special status if the UK and the EU had wanted to accept an entrustment.

Undoubtedly, this new form of sovereignty has brought great benefits and advantages to these territories, but the question is whether this is enough. There are numerous and increasingly relevant issues for these territories' future that, like Brexit, will remain outside of their direct control but will have a direct impact on them. These territories will have to keep trusting that the UK is able to represent their interests at the same time as it represents its own interests. This is not always possible, particularly if their interests conflict not only with those of the UK but also with one another's interests, given that the BOTs and Crown Dependencies are a heterogeneous set of territories.

Thus, regardless of the importance of other forms of sovereignty, the Brexit process has demonstrated that the traditional concept of national sovereignty remains the most relevant one. The fact is that all these territories must follow the decision of the UK even if they disagree with this decision and even though they possess high degrees of self-government. They have not had a chance to negotiate their own statuses with the EU. In the case of Gibraltar, this will likely result in a very undesirable consequence: increased vulnerability to actions by Spain. In this sense, for the Gibraltarian government, the EU has emerged as a kind of guarantor power, providing an additional level of institutional legitimacy and security for 
Gibraltar and as a source of reassurance for its political and diplomatic consistency towards the territory. Rather than assuming this works in tandem with diplomatic support from the UK government, Picardo's clear implication is that the EU provides a kind of security for Gibraltar that both transcends and mitigates political fluctuations at Westminster, the frequent 'churn' of Foreign Office ministers, and potential shifts in UK government foreign policy priorities (Benwell \& Pinkerton, 2016).

Events like Brexit should help these territories put their feet on the ground and realise that, at crucial times, Westphalian or traditional sovereignty matters, even if these territories enjoy the greatest degree of autonomy possible. These territories have been deprived of the ability to make critical decisions regarding their present and future. While it is true that there are other forms of sovereignty, none of them provide complete independence. Brexit proves that the Westphalian sovereignty model is more alive than ever.

Yusuf and Chowdhury (2019) explain that two recent facts necessitate a reconsideration of the current status of these territories. These facts are the recent sanctions and the Anti-Money Laundering Act 2018, which requires BOTs to create public registers of all businesses registered there, described by the Chief Minister of Gibraltar as an "unacceptable act of modern day colonialism" (Gibraltar Government, 2018). In addition, settling the status question of the BOTs has taken on new significance following the 2016 Brexit referendum as it raises the issue of the future relationships between the BOTs and the EU and possibly the UK.

These territories' statuses have also conditioned their relationship with the EU during Brexit negotiations. Not only has the UK sidelined these territories, but the EU has made no attempt to preserve their current relationship. The EU could have acted in a pragmatic way, simply preserving the rights acquired over more than 40 years by the citizens and institutions of these territories. Another possibility could have been for the EU to have granted special treatment to these territories through an ad hoc deal or an association agreement. Nevertheless, the EU has taken the easy road, justifying its lack of rapprochement with them on the grounds of their lack of sovereignty. Consequently, the paradiplomatic capacities or the new forms of sovereignty granted to these territories have not helped them in this crisis.

In short, Brexit has made it necessary for these territories to reflect deeply upon their current statuses. Even if these territories feel satisfied with their internal status, they need to consider updating it or at least including more mechanisms which allow them to actively participate in the international scene and represent their own interests in a direct way. If not, they will have to be ready for the UK to place its interests above their own in the event of any conflicts of interest between the parties. The updating of their statuses will need to be dealt with in a cautious manner and will surely require an ad hoc solution for each territory.

\section{Conclusions}

The Crown Dependencies and the BOTs are two different types of territorial entity which have resulted from unique historical and constitutional realities. Each of these entities includes very different territories, with different legal statuses and varying forms of self-administration and constitutional linkages with the UK. However, they also share similarities and challenges which enable an analysis of these territories as a complete set. They are both self-governing territories which fall under British sovereignty and face common challenges that directly impact on their internal and external capacities to decide on key issues. 
At an internal level, the Crown Dependencies and most of the BOTs enjoy a great level of self-government, and the UK government is only responsible for international relations, defence, and good governance. All issues related to their internal affairs fall under the competence of each of these territories. Of the powers for which the UK is responsible, the most controversial one is the good governance power. In practice, this means that if the UK regards good governance as not being assured by the local government, then the UK can impose direct rule on it. The circumstances in which the UK can impose direct rule have not been well developed, and it is unclear if the UK can impose direct rule on the Crown Dependencies because these have never been colonies of the UK. In any case, this subsidiary power reserved for the UK is an important restriction to the territories' internal self-government.

It is necessary to bear in mind that the concept of sovereignty has evolved over the centuries. The traditional concept of sovereignty has been displaced by new forms of sovereignty which fit better with these territories' realities. However, this does not mean that the traditional Westphalian form of sovereignty has been replaced; nation-states are still the principal agents of the international arena. It cannot be forgotten that the major issues in international relations, such as the conclusion of international treaties or full membership of international organisations, require these territories to be full sovereign subjects.

Brexit has made clear that further steps need to be taken to update these territories' sovereignty. In this sense, the UK has prioritised its interests over these territories' interests; the UK has not been able to directly involve these territories in the withdrawal negotiations with the EU and has not been able to secure a special deal with the EU that could allow these territories to keep their current EU statuses. The UK has mechanisms such as entrustment which could have helped these territories conclude their own agreements with the EU, but the UK decided not to use them. Moreover, none of these territories, except for Gibraltar, could participate in the 2016 Brexit referendum. All the territories had to accept a decision about which they were not consulted, and in the case of Gibraltar, voters had to accept a decision with which they did not agree. Given the heterogeneity of their EU statuses and interests, it would furthermore be impossible for the UK to satisfy all interests to the same degree.

External issues will continue having a direct impact on these territories' internal governments, but many decisions will be outside their direct control. In short, even if these territories are content with their current status, Brexit necessitates that they explore new formulas which make them less vulnerable to UK unilateralism. These new formulas should allow them to enhance their international capacities in order to make decisions regarding international events that can seriously impact their present and future situation.

\section{References}

Armstrong, H.W., \& Read, R. (2000). Comparing the economic performance of dependent territories and sovereign microstates. Economic Development and Cultural Change, 48(2), 285-306. https://doi.org/10.1086/452459

Auld, R. (2013). Turks and Caicos Islands Commission of Inquiry. Retrieved from https://www.gov.uk/government/publications/turks-and-caicos-islands-commissionof-inquiry-2008-2009

Baldacchino, G. (2017). Solution protocols to festering island disputes: 'Win-win' solutions for the Diaoyu / Senkaku Islands. https://doi.org/10.4324/9781315574707-5 
Barrow, C. (2005). The return of the state: Globalization, state theory, and the new imperialism. New Political Science, 27(2), 123-145. https://doi.org/10.1080/07393140500098235

Barrow, C., \& Keck, M. (2017). Globalization theory and state theory: The false antinomy. Studies in Political Economy, 98(2), 177-196. https://doi.org/10.1080/07078552.2017.1342999

Bartmann, B. (2006). In or out: Sub-national island jurisdictions and the antechamber of paradiplomacy. The Round Table, 95(386), 541-559. https://doi.org/10.1080/00358530600929974

BBC News (2016, April 5). Panama papers Q\&A: British Overseas Territories and Crown Dependencies. Retrieved from https://www.bbc.com/news/uk-35969481

Benwell, M.C., \& Pinkerton, A. (2016). Brexit and the British Overseas Territories. RUSI, 161(4).

Bishop, M.L., \& Clegg, P. (2018). Brexit: Challenges and opportunities for small countries and territories. The Round Table, 107(3), 329-339. https://doi.org/10.1080/00358533.2018.1476093

Boswell, A. (2018). Brexit: The Crown Dependencies (European Union Committee Report)— Question for Short Debate. Retrieved from https://www.theyworkforyou.com/lords/?id=2018-01-23a.993.0

Caribbean Council (2019). Brexit and the UK Overseas Territories. The Caribbean council. https://www.caribbean-council.org/brexit-uk-overseas-territories/

Clegg, P. (2016). Brexit and the Overseas Territories: Repercussions for the periphery. The Round Table, 105(5), 543-555. https://doi.org/10.1080/00358533.2016.1229420

Clegg, P. (2018). The United Kingdom and its Overseas Territories: No longer a 'benevolent patron'? Small States \& Territories, 1(2), 149-168.

Council of the European Union (2019). Proposal for a Regulation of the European Parliament and of the Council amending Council Regulation (EC) No 539/2001. Retrieved from https://www.consilium.europa.eu/media/38044/st05960-en19.pdf

DQ Law Firm (2016). Brexit: The impact on the Isle of Man. Retrieved from https://dq.im/brexit-the-impact-on-the-isle-of-man/

European Commission (2019a). List of overseas countries and territories. EU Trade Helpdesk. Retrieved from https://trade.ec.europa.eu/tradehelp/overseas-countries-and-territories

European Commission (2019b). Overseas countries and territories. International cooperation development. Retrieved from https://ec.europa.eu/europeaid/regions/octs en

European Court of Human Rights (1999). Judgment in the case of Matthews $v$. The United Kingdom, 18 February 1999 (application n no. 24833/94).

European Sources Online (2019). Ministers meet Overseas Territories to engage in Brexit process. Retrieved from https://www.europeansources.info/record/ministers-meet-overseasterritories-to-engage-in-brexit-process/

García, J. (1994). Gibraltar-the making of a people. Gibraltar: Medsun.

Gibraltar Government (2006). Constitution of Gibraltar, 14 December. Retrieved from https://www.gibraltarlaws.gov.gi/constitution/Gibraltar_Constitution Order 2006.pdf

Gibraltar Government (2019). Treaty of Utrecht 13 July 1713. Retrieved from http://www.gibnet.com/texts/utrecht.htm 
Gibraltar Government (2018). Press release: Letter from Chief Minister to Rt Hon Andrew Mitchell MP, 11 May. https://www.gibraltar.gov.gi/new/sites/default/files/press/2018/Press\%20Releases/2 42.3-2018.pdf

Gibraltar Insight (2018, September 1).Representation in Westminster. Retrieved from https://issuu.com/gbzmedia/docs/gbz0818 gi magazine sept 0409 singl

Ginnangeli, M. (2018). Give Gibraltar an MP: Rock demands Westminster presence as fears mount of Brexit snatch. The Express. Retrieved from https://www.express.co.uk/news/politics/968779/Gibraltar-MP-Rock-Westminstervote-Brexit

Gold, P. (2016). Gibraltar: A paradigmatic presqu'ile? Shima, 10(1), 21-32.

Grydehøj, A. (2016). Navigating the binaries of island independence and dependence in Greenland: Decolonisation, political culture, and strategic services. Political Geography, 55, 102-112. https://doi.org/10.1016/j.polgeo.2016.09.001

Hare, P. (2017). Brexit will hit Britain's Overseas Territories hard—why is no one talking about it? The Independent. Retrieved from https://www.independent.co.uk/voices/brexit-britain-overseas-territories-impactuk-negotiations-talks-gibraltor-caribbean-a7980546.html

Hendry, I., \& Dickson, S. (2018). British Overseas Territories law. United Kingdom: Hart.

House of Commons Foreign Affairs Committee (2008). Overseas Territories. Seventh Report of Session 2007-08.

House of Commons Justice Committee (2010). Crown Dependencies. Eighth Report of Session 2009-10.

House of Lords. European Union Committee (2017a). Brexit: Gibraltar, 13th Report of Session 2016-17.

House of Lords European Union Committee (2017b, July 10). Corrected oral evidence: Brexit: Overseas Territories. Retrieved from http://data.parliament.uk/writtenevidence/committeeevidence.svc/evidencedocume nt/european-union-committee/brexit-overseas-territories/oral/69288.pdf

House of Lords. European Union Committee (2017c). Brexit: The Crown Dependencies, 19th Report of Session 2016-17.

Jersey Evening Post (2017, August 9). Jersey 'should have MP in Westminster'. Retrieved from https://jerseyeveningpost.com/news/2017/08/09/jersey-should-have-mp-inwestminster/

Marre, O. (2018). The Status of Gibraltar under EU Law. Chancery Bar. Retrieved from https://www.chba.org.uk/for-members/library/overseas-seminars/the-status-ofgibraltar-under-eu-law

Miller, V. (1995). Gibraltar, Research paper 95/80. International Affairs in Defence, House of Commons Library. Retrieved from https://commonslibrary.parliament.uk/researchbriefings/rp98-50/

Miller, V. (2017). Brexit and Gibraltar. House of Commons Library briefing paper, (7963). Ministry of Justice (2019). Fact sheet on the UK's relationship with the Crown Dependencies. Retrieved from https://www.justice.gov.uk/downloads/about/moj/ourresponsibilities/crown-dependencies-factsheet.pdf 
Mut-Bosque, M. (2018). Ten different formulas for Gibraltar post-Brexit. DCU Brexit Institute$\begin{array}{lllll}\text { Working } & \text { paper } & \text { N. } & \text { Retrieved }\end{array}$ https://papers.ssrn.com/sol3/papers.cfm?abstract id=3212246

Prinsen, G., \& Blaise, S. (2017). An emerging 'Islandian' sovereignty of non-self-governing islands. International Journal, 72(1), 56-78. https://doi.org/10.1177/0020702017693260

Protocol no 3 on the Channel Islands and the Isle of Man (1972). Treaty of Accession of the United Kingdom of Great Britain and Northern Ireland, Official Journal of the European Communities, L 73, 27 March 1972, OJ L 73, 27.3.1972. P. 164

Skinner, J. (2002). British constructions with constitutions: The formal and informal nature of 'island' relations on Montserrat and Gibraltar. Social Identities, 8(2), 301-320. https://doi.org/10.1080/13504630220151584

Sutton, A. (2019). Relics of Empire or full partners of a new global United Kingdom? The impact of Brexit on the UK Crown Dependencies and Overseas Territories. The Constitution Society, Report 4-158. Retrieved from https://consoc.org.uk/wpcontent/uploads/2018/06/Alastair-Sutton-Relics-of-Empire-or-Full-Partners-of-a-

New-Global-United-Kingdom.pdf

The Local (2016, March 7). Gibraltar is passionately British-That's why we reject Brexit. Retrieved from https://www.thelocal.es/20160307/gibraltar-is-passionately-britishthats-why-we-reject-brexit-fabian-picardo

The Parliament of the Isle of Man (2019). Tynwald: the Oldest Continuous Parliament in the World. Retrieved from http://www.tynwald.org.im/Pages/default.aspx

Trinidad, J. (2017). Gibraltar, Brexit and the impossibility of 'leaving Europe'. E-International Relations. Retrieved from https://www.e-ir.info/2017/03/02/gibraltar-brexit-andthe-impossibility-of-leaving-europe/

UK Government (2009). The Turks and Caicos Islands Constitution (Interim Amendment) Order 2009, No $701 . \quad$ Retrieved from http://www.legislation.gov.uk/uksi/2009/701/contents/made

UK Parliament (2017). The implications of Brexit for the Crown Dependencies: Conclusions and recommendations. $\quad$ Retrieved from https://publications.parliament.uk/pa/cm201617/cmselect/cmjust/752/75206.htm\# idTextAnchor014

U.S. Department of the Treasury (2014). Foreign Account Tax Compliance Act. Retrieved from https://home.treasury.gov/about/offices/tax-policy/foreign-account-tax-compliance-act

Wheatley, B. (2018). British Virgin Islands, Brexit and beyond: What future for small jurisdictions? Presentation at University of the West of England, Bristol, 14 March.

World Population Review (2019). Bermuda population 2019. Retrieved from http://worldpopulationreview.com/countries/bermuda-population/

Worldometers (2019a). Channel Islands population. Retrieved from http://www.worldometers.info/world-population/channel-islands-population/

Worldometers (2019b). Isle of Man population. Retrieved from http://www.worldometers.info/world-population/isle-of-man-population/

Yusuf, H.O., \& Chowdhury, T. (2019). The persistence of colonial constitutionalism in British Overseas Territories. Global Constitutionalism, 8(1), 157-190. https://doi.org/10.1017/s2045381718000369 